neofilolog

Czasopismo Polskiego Towarzystwa Neofilologicznego

ISSN 1429-2173, elSSN 2545-3971, 2020, NR 54/1, 71-85

http://dx.doi.org/10.14746/n.2020.54.1.5

http://poltowneo.org/

Katarzyna Posiadała

Uniwersytet Warszawski https://orcid.org/ 0000-0002-8053-7574 posiadala.k@gmail.com

\title{
KSZTAŁTOWANIE UMIEJĘTNOŚCI AUTOEWALUACJI U UCZĄCYCH SIĘ JĘZYKA OBCEGO W WIEKU 55+
}

\author{
Development of self-assessment skills \\ of foreign language learners aged 55+
}

Self-assessment is a key learning strategy for autonomous language learning, enabling learners to become more aware of the learning process, more ready to take responsibility for their own learning, empowered to make their own changes and to relate learning to individual needs. Also it may help learners to become more aware of their own strengths and weaknesses, as well as of strategies which best suit their particular learning styles and hence to become more reflective and autonomous explorers of language. This paper discusses why self-assessment is important in the toolkit of foreign language learners aged 55+and presents techniques which help develop self-assessment skills in foreign language learning in this group of learners. One of the most effective self-assessment tools in working with students aged 55+is The European Language Portfolio.

Keywords: Self-assessment, foreign language learning, learners aged 55+, European Language Portfolio

Słowa kluczowe: autoewaluacja, samoocena, uczenie się języków obcych, uczący się w wieku 55+, Europejskie Portfolio Językowe 


\section{Wprowadzenie}

Autoewaluacja jest to jeden z rodzajów ewaluacji wewnętrznej dokonywanej przez osobę, która jest związana z podmiotem ewaluacji. M oże się ona odbywać na poziomie instytucjonalnym, np. autoewaluacja szkoły, albo na poziomie jednostki, np. autoewaluacja nauczyciela lub uczącego się. Autoewaluacja uczącego się polega na stałej obserwacji swojej pracy, analizowaniu sukcesów i niepowodzeń, a także czynników wpływających na efektywność własnych posunięć oraz obserwowaniu kierunku zmian prowadzących do rozwoju, który jest głównym zadaniem działania edukacyjnego (Jaworska, 2009: 36). W procesie uczenia się i nauczania języków obcych autoewaluacja dotyczy systematycznego procesu zbierania informacji na temat własnej językowej kompetencji komunikacyjnej, kompetencji uczenia się, których uzyskanie pozwala na sformułowanie wniosków o ich wartości i poczynionych postępach. Są one gromadzone na podstawie określonych celów, kryteriów i wartości, a na ich podstawie możliwe staje się planowanie dalszych działań. Celem autoewaluacji jest więc poprawa i udoskonalenie procesu uczenia się. M oże ona odnosić się do postępów uzyskanych po pewnym etapie i pozwolić ocenić poziom wiedzy i umiejętności (autoewaluacja sumatywna), może też dotyczyć przebiegu procesu uczenia się i jego doskonalenia (autoewaluacja formatywna).

W niniejszych rozważaniach autoewaluacja dotyczy autorefleksji własnych działań uczących się, które prowadzą do pracy nad sobą, do doskonalenia własnego procesu opanowywania języka obcego i planowania własnego rozwoju. Celem artykułu jest ukazanie problematyki związanej z kształtowaniem umiejętności autoewaluacji u osób w wieku 55+. Stanowi on przyczynek do dyskusji nad rolą i miejscem autoewaluacji w systemie edukacji ustawicznej skierowanej na rozwijanie autonomii uczących się, proponując jednocześnie rozwiązania wspomagające kształtowanie umiejętności dokonywania samooceny u uczących się w wieku 55+. Artykuł skierowany jest przede wszystkim do nauczycieli języków obcych pracujących z osobami 55+, a także do nauczycieli akademickich kształcących przyszłych nauczycieli języków obcych.

\section{Autoewaluacja z perspektyw psychologicznej i glottodydaktycznej}

Z perspektywy psychologicznej, autoewaluacja to aspekt poznawczy poczucia własnej wartości. Jest ona traktowana jako integralna część i czynnik wartościująco-oceniający obrazu własnej osoby (Palak, 1988, za: Gindrich, 2002: 53). Na obraz ten składają się wyobrażenia i myśli o sobie (samowiedza) dotyczące m.in.: wyglądu zewnętrznego, umiejętności, zdolności, cech charakteru, potrzeb, motywów działania, pozycji społecznej, czyli właściwości fizycznych, 
Kształtowanie umiejętności autoewaluacji u uczących się języka obcego w wieku...

psychicznych i społecznych (Niebrzydowski, 1976: 52; Kozielecki, 1981: 76; Adamus, 2004: 64). Samowiedza jest podstawą samorozwoju człowieka. Podczas oceniania siebie człowiek uwzględnia rezultaty własnych działań, analizuje informacje o sukcesach i porażkach, bierze też pod uwagę opinie i oceny formułowane przez innych ludzi. Autoewaluacja pozwala wyodrębnić człowieka ze środowiska (Baumann, 2005: 27-28), pozwala mu także dopasować siły do zadań i wymogów otoczenia, aby w ten sposób określić swoje możliwości i cele (Kulas, 1983; Szmagaj, 2002: 59). Samoocena postrzegana jest przez psychologów jako mechanizm regulujący, gdyż jest ona wewnętrznym punktem odniesienia, który pozwala jednostce określić poziom wymagań względem siebie oraz rodzaj działań, jakich człowiek jest w stanie się podjąć (Kulas, 1983).

Koniecznym warunkiem autoewaluacji jest przejęcie kontroli nad własnym procesem uczenia się. Zgodnie z psychologiczną teorią umiejscowienia kontroli jednostka postrzega skutki swojego zachowania bądź jako działania przez nią kontrolowane (poczucie kontroli wewnętrznej), bądź pozostające poza jej kontrolą (poczucie kontroli zewnętrznej). Osoby o poczuciu kontroli wewnętrznej uważają, że skutki ich postępowania są uzależnione od zachowania. Cechuje je wiara we własne możliwości i siły, są aktywne i zmotywowane do działania. Osoby o poczuciu kontroli zewnętrznej, nie wierzą we własne siły, wskutek czego pozostają bierne i nie wykazują zaangażowania w działania (Rotter, 1966: 1-2; Drwal, 1995: 199). W zakres kontroli osobistego działania wchodzi także poczucie własnej skuteczności (Bandura, 1997). Im silniejsze są przekonania jednostki co do jej własnej skuteczności, tym wyższe cele sobie stawia i tym silniejsze jest jej zaangażowanie w zamierzone działanie (Locke i Latham, 1990). Silne poczucie skuteczności skłania więc jednostkę do zainwestowania większego wysiłku w działanie, niskie - wiąże się z postawą pasywną, której towarzyszyć mogą, depresja oraz bezradność (Juczyński, 2000: 11). Niepowodzenia dla osób z wyższym poczuciem skuteczności stają się możliwością uczenia się na błędach, natomiast osoby z poczuciem niższym odbierają je jako katastrofę. Budowanie wysokiego poczucia skuteczności jest możliwe tylko wtedy, kiedy jednostka ma określony cel działania i wie, jakich technik i metod użyć, aby go osiągnąć (Schunk i Ertmer, 1999: 251n). Poziom samooceny ma również wpływ na relacje jednostki z innymi ludźmi i jej sposób funkcjonowania w społeczeństwie (Kulas, 1983).

Z perspektywy glottodydaktycznej autoewaluacja jest odpowiedzią na potrzeby edukacyjne uczącego się, a jej celem jest zwiększenie jego zaangażowania w proces uczenia się języka, przejęcie za niego odpowiedzialności, rozwinięcie świadomości językowej i metakognitywnej, a także kształtowanie umiejętności krytycznego spojrzenia na proces kształcenia oraz uzyskane efekty. Polega ona na diagnozowaniu własnych mocnych i słabych stroni często przyczynia się do wzrostu motywacji do nauki. 
Jednym z kluczowych elementów autoewaluacji jest wiedza metakognitywna, która obejmuje wiedzę deklaratywną i proceduralną (Rampillon i Zimmermann, 1997: 43). Deklaratywna wiedza metakognitywna dotyczy wiedzy eksplicytnej na temat własnych oraz cudzych procesów poznawczych, natomiast proceduralna wiedza metakognitywna dotyczy wiedzy i umiejętności z zakresu ich planowania, monitorowania, a także ewaluacji. W literaturze przedmiotu wymienia się następujące kategorie klasyfikowania wiedzy metakognitywnej:

- wiedza o uczącym się (wiedza m.in. o jego potrzebach indywidualnych, stylach uczenia się, zainteresowaniach, a także o jego możliwościach i mocnych oraz słabych stronach);

- wiedza o grupie/kulturze (rozumiana jako zrozumienie norm oraz oczekiwań w danej grupie/ kulturze);

- $\quad$ wiedza o zadaniu (odnosi się do celu zadania językowego oraz potrzeb związanych z jego realizacją);

- $\quad$ wiedza o całym procesie uczenia się (obejmuje specyfikę procesu uczenia się języka obcego jako procesu długotrwałego, trwającego przezcałe życie);

- wiedza o strategiach uczenia się języka obcego (dotyczy wiedzy o dostępnych strategiach uczenia się i strategiach metakognitywnych);

- wiedza warunkowa (czerpie informacje z wcześniej wymienionych rodzajów wiedzy i umożliwia odpowiedzi na pytania: kiedy, dlaczego i jak używać strategii) (Flavell, 1978; Wenden, 1991; Oxford, 2017: 155-156).

W procesie rozwoju umiejętności autoewaluacji niezbędna jest wiedza o strategiach metakognitywnych, które obejmują: zwrócenie uwagi na działania językowe; planowanie; organizowanie procesu uczenia się i pozyskiwanie do tego celu zasobów; monitorowanie i ewaluację procesu uczenia się języka obcego (Oxford, 2017: 155). Zwrócenie uwagi obejmuje świadomą koncentrację na działaniach językowych, np. na tym, co nauczyciel mówi w klasie, co uczeń ma za zadanie zrobić, co mówią inni uczący się itd. Strategie związane z planowaniem, to m.in.: pogłębianie wiedzy na temat procesu uczenia się, formułowanie precyzyjnych i realistycznych celów krótko- i długoterminowych oraz sposobów ich osiągania, identyfikowanie celu danego zadania językowego i zaplanowanie jego realizacji, ocena czasu potrzebnego na uczenie się danego zakresu materiału do nauki, stawianie pytań na temat dotychczasowej wiedzy dotyczącej danego zagadnienia, ustanowienie priorytetów w uczeniu się, stworzenie planu odpowiadającego potrzebom indywidualnym uczącego się. Strategie związane z organizowaniem procesu uczenia się i pozyskaniem do tego zasobów obejmują działania polegające na tworzeniu optymalnych warunków do pracy sprzyjających efektywnemu uczeniu (np. zaplanowaniu czasu i miejsca), na odsunięciu od siebie wszystkiego, co rozprasza 
Kształtowanie umiejętności autoewaluacji u uczących się języka obcego w wieku...

(np. zapewnieniu ciszy w trakcie nauki) oraz zebraniu materiałów niezbędnych do nauki (np. zorganizowaniu plików w komputerze, aby można było je szybko odnaleźć, zorganizowaniu pomocy i materiałów dydaktycznych do nauki języka obcego), a także na określeniu zakresu materiału do nauczania oraz stopnia, w jakim ma być on opanowany, a także doborze odpowiednich strategii i technik uczenia się). Strategie związane z monitorowaniem i ewaluacją jakości uczenia się dotyczą aktywnego systematycznego rejestrowania własnych postępów i związane są z samooceną uczącego się. Składają się na nie takie działania, jak $\mathrm{np}$.: stawianie pytań na temat przyrostu wiedzy i stopnia opanowanego materiału do nauki (np. czy cel został osiągnięty, jeżeli nie - dlaczego i co należy poprawić, aby go osiągnąć), porównywanie efektu uczenia się z oczekiwaniami, sprawdzanie tempa pracy, porównywanie stanu wykonania z postawionym wcześniej celem, rozpoznanie ewentualnych błędów oraz próba ich eliminacji (Oxford, 2017: 181-182). Stosowanie strategii metakognitwnych pozytywnie wpływa na proces uczenia się. Pomaga go monitorować i sprawniej kontrolować, rozwija autorefleksję, pozwala także wyjść uczącemu się poza dotychczasowe nawyki i przyzwyczajenia, gdyż pomaga spojrzeć na proces nauki z innej perspektywy. Uczący się, którzy efektywnie stosują strategie metakognitywne, są bardziej zaangażowani i zmotywowani do uczenia się, podnosząc swoje umiejętności nawet o 20-46\% (Gage i Berliner, 1996: 322). Warunkiem fortunnej autoewaluacji jest umiejętnie przeprowadzony proces samopoznania, tj. samodzielnego zdobywania informacji o sobie samym i o swoim procesie uczenia się, ważna jest także zdolność do formułowania realistycznej oceny wyników własnej pracy względem zakładanych oczekiwań (Jaworska, 2009: 60).

Proces kształtowania umiejętności samooceny trwa całe życie (Kulas, 1986; Niebrzydowski, 1976), sposób jej dokonywania może bowiem ulegać zmianom na skutek doświadczeń uczącego się oraz odnoszonych sukcesów lub niepowodzeń (Niebrzydowski, 1989). Umiejętność samooceny sprzyja zaś kształtowaniu autonomii, gdzie odpowiedzialność za proces nauki zostaje przeniesiona z nauczyciela na uczącego się (Gardner, 2000; Zimmerman, 2002), który stopniowo odkrywa i uświadamia sobie własne możliwości i uwarunkowania, uczy się też wybierać to, „co wydaje się najbardziej słuszne w perspektywie osobistego doskonalenia obcojęzycznego" (Wilczyńska, 1999: 129).

\section{Autoewaluacja w procesie uczenia się/ nauczania języków obcych u osób 55+}

Kształtując umiejętność autoewaluacji w procesie uczenia się języków obcych u osób w wieku 55+, niezbędne jest poznanie wiedzy na temat ich potencjału uczeniowego. Kształcenie językowe tej grupy docelowej wpisuje się w obszar glottogeragogiki - bardzo młodej subdyscypliny łączącej w wymiarze teoretycznym 
i praktycznym - wiedzę i doświadczenia pozyskane w wyniku badań glottodydaktycznych i geragogicznych (Kic-Drgas, 2013; Jaroszewska, 2014: 64,).

Grupa uczących się 55+obejmuje najszerszą grupą uczących się, w której występuje najszersze spektrum różnic indywidualnych. Według ustaleń Światowej Organizacji Zdrowia (ang. World Health Organization - WHO) obejmuje ona osoby: w wieku przedstarczym (45-59 lat), w wieku wczesnej starości (60-74 lata), osoby w wieku późnej starości (75-89 lat) oraz osoby długowieczne (90 lat i więcej). Podział ten uwzględnia sprawność psychofizyczną, nie oznacza to jednak, że u poszczególnych osób należących do wyodrębnionych przedziałów wiekowych tempo dokonujących się zmian jest podobne. Proces starzenia się jest silnie zindywidualizowany i u każdego człowieka przebiega inaczej. Anna Jaroszewska (2011: 494-497) wyróżniła zespół cech reprezentatywnych, które w tej grupie wiekowej pojawiają się statystycznie najczęściej. Jedne mogą wspierać, inne zaś utrudniać dokonanie autoewaluacji. Cechy te obejmują trzy podstawowe sfery aktywności życiowej człowieka: biologiczną, psychologiczno-podmiotową oraz sferę życia społecznego.

W aspekcie biologicznym część osób w wieku 55+zachowuje dobry stan zdrowia, jest w świetnej kondycji fizycznej, ma wciąż dobry słuch i wzrok, u innych natomiast można już zauważyć początek procesów regresywnych. Organizm człowieka doświadcza zmian w podstawowych układach, co wpływa na percepcję zmysłową (wzrokową i słuchową), obniżenie sprawności i wydolności fizycznej oraz występowanie czy też nasilenie się chorób, które mogą skutkować m.in. obniżeniem sprawności psychomotorycznych. Wynikiem łącznego wpływu zmian biologicznych związanych ze starzeniem się u osób 55+ pojawia się: mniejsza odporność na stres, słabsza odporność immunologiczna czy obniżenie zdolności do adaptacji.

W aspekcie psychologiczno-podmiotowym u zdrowych osób 55+ wiedza i pewne umiejętności, takie jak zdolność rozwiązywania codziennych problemów, umiejętność praktycznego wnioskowania, zasób słów, funkcjonowanie uwagi, koncentracji w czasie rozwiązywania zadań, zdolność rozróżniania między tym, co ważne, a tym, co nieistotne, pozostają niezmienne (Szatur-Jaworska i in., 2006: 53). Osoby te bez problemu za pomocą myślenia retrospektywnego mogą odtworzyć wydarzenia sprzed kilkudziesięciu lat, posiadają ogromny bagaż doświadczeń, dzięki któremu z rozwagą podejmują decyzje i z większym dystansem podchodzą do otaczającej ich rzeczywistości (Grudziński, 2012: 53). Do cech sprzyjających dokonaniu samooceny należą także, m.in.: zdolność do autentycznej ekspresji emocjonalnej, utrzymywanie się wysokiej zdolności myślenia abstrakcyjnego, silne zmotywowanie do nauki, zróżnicowane zainteresowania, czy też posiadanie doświad czenia w uczeniu się języka obcego (Jaroszewska, 2011: 494-497). Wraz z upływem lat mogą natomiast 
Kształtowanie umiejętności autoewaluacji u uczących się języka obcego w wieku...

pojawić się niekorzystne zmiany w sferze poznawczej i intelektualnej (zob. Zych i Kaleta-Witusiak, 2010: 30). Do cech, które mogą negatywnie wpłynąć na samoocenę należą m.in.: stany depresyjne, związane z szeroko rozumianymi deficytami związanymi z procesem starzenia się, umocnienie się cech osobow ości introwertycznej, negatywne doświadczenia w zakresie uczenia się języków obcych, osłabienie się selektywności uwagi i zdolności do długotrwałej koncentracji, regresywne zmiany w zakresie inteligencji płynnej, nienadążanie za tempem prowadzonych zajęć, czy skłonności do szybkiego męczenia się w aspekcie intelektualnym ${ }^{1}$.

W aspekcie społecznym osoby 55+mają duży bagaż doświadczeń, podejmowały w swoim dotychczasowym życiu wiele ról społecznych, które wymagały od nich ciągłego przeformułowania wiedzy i kompetencji. U niektórych ma miejsce zakończenie aktywności zawodowej, stąd też mają więcej czasu wolnego. Charakteryzuje jetakże potrzeba wiedzy, rozwoju nowych kompetencji, potrzeba akceptacji przez najbliższych i przez otoczenie, a także potrzeba przynależności do określonej grupy społecznej (Jaroszewska, 2013: 77). Do cech społecznych sprzyjających dokonaniu autoewaluacji u uczących się w wieku 55+ należą: silna potrzeba samorealizacji, samowystarczalności i samodecydowania o sobie, potrzeba aktywności, kontaktów personalnych, potrzeba weryfikacji swoich możliwości i zachowania dotychczasowej sprawności intelektualnej. Dokonanie autoewaluacji w wymiarze społecznym utrudniają im m.in. złe samopoczucie, jeśli znajdą się w grupie uczących się w młodszym wieku, a także praca pod kierunkiem zbyt młodego nauczyciela. M ożliwe są też przerwy w nauce, które wynikają z chorób, czy innych obowiązków, np. rodzinnych, co skutkuje przesunięciem terminów realizacji ustalonych celów. Wraz z wiekiem wzrasta też skłonność do porównań społecznych, w szczególności w relacji „ja-inni”, która z jednej strony może motywować, wzmagać autonomię, czy chęć samorozwoju, może też jednak potęgować frustrację, zazdrość, poczucie porażki, które mogą negatywnie wpływać na obraz własnej osoby i w efekcie zaniżać samoocenę. Niektórzy uczący się w wieku 55+mogą

\footnotetext{
${ }^{1}$ Cechy te mają też znaczący wpływ na proces uczenia się/nauczania języków obcych, gdyż można zauważyć trudności niektórych uczących się w tej grupie wiekowej m.in. w rozumieniu tekstu czytanego z powodu osłabienia narządu słuchu, rozumieniu tekstu pisanego, którego czcionka jest nieodpowiedniej wielkości, nieodpowiedniego kształtu lub z nieostrym kontrastem. Charakterystyczne dla tej grupy uczących się są również problemy funkcjonowaniem pamięci roboczej i występowanie tzw. luk w pamięci, które objawiają się np. chwilowym zapomnieniem danego wyrazu w języku obcym. Osłabieniu mogą ulegać zdolności kombinacyjne, myślenie logiczno-abstrakcyjne, a także przerzutność uwagi (Grudziński, 2012: 53).
} 
też mieć przeświadczenie o niższej wartości i tendencję do częstszego i silniejszego poczucia niezadowolenia z siebie, a także zwiększone odczuwanie lęku i osamotnienia, przez co mogą gorzej oceniać swoje możliwości intelektualne. Niska samoocena wpływa negatywnie na funkcjonowanie człowieka, od jej poziomu zależy m.in. nastawienie człowieka do napotykanych trudności, sposób reagowania na stawiane zadania, efektywność działania oraz relacje interpersonalne. Uczący się z niską samooceną przypisuje sobie możliwości mniejsze od rzeczywiście posiadanych, a więc nie docenia swoich umiejętności i sukcesów, a przecenia porażki. Do przyczyn niskiej samooceny należą: duża wrażliw ość na ocenę i krytykę ze strony otoczenia oraz stały strach przed niepowodzeniem lub ośmieszeniem się (Niebrzydowski, 1989: 29).

Osoby 55+ bywają też przywiązane do klasycznych metod nauczania, które poznały w okresie swojej młodości. Mają określone nawyki uczenia się, wykazują mniejszą elastyczność w kontekście nowych rozwiązań dydaktycznych niż osoby młodsze. Nowe metody pracy, a do takich należy samoocena powinny być więc wprowadzane stopniowo, gdyż w przeciwnym razie mogą powodować niepokój, a nawet demotywację do dalszej nauki. Uczący w tej grupie wiekowej mają również silnie zakorzenione stereotypy i uprzedzenia względem określonych wartości, czy np. grup społecznych. One także mogą powodować trudności w kształtowaniu umiejętności autoewaluacji.

Pod względem autonomii uczenia się niektórzy uczący się w wieku 55+ charakteryzują się całkowitą zależnością od nauczyciela. W polskim systemie oświatowym przez wiele lat to nauczyciel był w centrum procesu kształcenia, był źródłem wiedzy i autorytetem. To do niego należało ocenianie. Ocena nauczyciela była ostateczna i nie podlegała dyskusji. W rezultacie uczący się w wieku 55+mogą mieć trudności w dokonywaniu samooceny, przede wszystkim, dlatego, że jest to dla nich pewne novum, w którym wkraczają w kompetencję postrzeganą jako wyłącznie nauczycielską (Steinbrich, 2015: 34). W budowaniu poczucia własnej wartości uczącego, a także w rozwoju jego umiejętności autoewaluacji ważną rolę odgrywają więc nauczyciele (Berndt, 2000: 7). Nauczyciele prezentujący wysoki poziom samooceny potrafią w toku interakcji przekazać uczącemu się wiarę w jego potencjał. Z kolei nauczyciele o niskiej samoocenie są raczej skupieni na słabych stronach uczącego się, manipulują nim i wymuszają posłuszeństwo (Biernat, 2016: 162).

W grupie osób 55+samoocenę należy przeprowadzać wyjątkowo umiejętnie, z dużą dozą wrażliwości i akceptacji względem słabości, które powstały wskutek dysfunkcji związanych z procesem starzenia się organizmu. źle przeprowadzona samoocena może wywoływać negatywne nastawienie do zajęć językowych, nauczyciela oraz dalszej nauki, skutkować utratą motywacji czy obniżeniem samooceny (Jaroszewska, 2009: 87-88; Berndt, 2003). Pracując 
Kształtowanie umiejętności autoewaluacji u uczących się języka obcego w wieku...

z osobami 55+, pomocna jest wstępna rzetelna diagnoza, która ma posłużyć dostarczeniu informacji o ich potrzebach, możliwościach, indywidualnych stylach uczenia się, zainteresowaniach (Berndt, 2003: 232) oraz wiedzy strategicznej (m.in. obejmującej dostępne strategie uczenia się i strategie metakognitywne).

\section{Kształtowanie umiejętności autoewaluacji w procesie uczenia się języków obcych u osób 55+}

Kształtowanie umiejętności autoewaluacyjnych dotyka wielu obszarów, w tym: formułowania celów uczenia się, wykorzystywania strategii i technik uczenia się, odpowiedniego stosowania kryteriów oceniania i narzędzi samooceny. Rozwijanie tych umiejętności u osób 55+obejmuje m.in.:

- poznanie siebie jako osoby uczącej się języków obcych (poznanie swoich potrzeb, możliwości, mocnych i słabych stron, rozpoznanie własnego stylu uczenia się oraz akceptację ewentualnych deficytów związanych z procesem starzenia się organizmu);

- refleksję nad własnymi procesem uczenia się i stosowanymi strategiami, w tym strategiami metakognitywnymi (rozpoznanie efektywnych strategii uczenia się języków obcych oraz rozwinięcie repertuaru strategii uczenia się poprzez trening strategiczny);

- uświadomienie znaczenia autoewaluacji (zmiana przyzwyczajeń, stereotypowych opinii i sądów);

- stopniowe i systematyczne wdrażanie narzędzi do autoewaluacji swoich postępów w poznawaniu języków i kultur (np. stosowanie strategii metakognitywnych, stosowanie technik autoewaluacyjnych);

- zdobycie samodzielności w nauce języków;

- stworzenie odpowiednich warunków do kształtowania autoewaluacji (nauczyciele, materiały dydaktyczne, media, przekaz informacji), a także stosowanie narzędzi dydaktycznych, których zastosowanie ma na celu umożliwienie bądź ułatwienie samooceniania.

Samoocena dokonuje się w umyśle człowieka, jest to proces nieświadomy. Uświadomienie tego procesu jest możliwe poprzez zastosowanie odpowiednich technik autoewaluacyjnych, które mają na celu dostarczenie informacji na temat wiedzy i kryteriów, które pozwolą na zobiektywizowanie procesu uczenia się i nabraniu dystansu do nich, aby uzyskać nad nimi kontrolę (Kaczmarek, 2002: 70). Kształtowanie umiejętności opisywania własnego procesu uczenia się poprzez zbieranie, analizowanie i pozyskanych informacji na temat własnego procesu uczenia się języka obcego wymaga indywidualnego podejścia do uczącego się i odejście od nauczania frontalnego. Do technik autoewaluacyjnych, 
które mogą zostać wykorzystane w grupie osób 55+zalicza się m.in. ocenę koleżeńską, dziennik uczenia się, konsultację, listy umiejętności, arkusz obserwacyjny, krótkie podsumowanie zajęć i prowadzenie portfolio.

Ocena koleżeńska to wzajemne poprawianie wypowiedzi/zadań przez koleżanki/kolegów z grupy językowej. Dzięki niej możliwe jest rozwijanie umiejętności identyfikowania problemów uczenia się. Pozwala ona na sformułowanie opinii na temat wypowiedzi obcojęzycznej i poznanie różnych punktów widzenia. Jest uważana za jedną z bardziej efektywnych technik oceniania (Wilczyńska, 1999: 259). W grupie uczących się 55+ocenę koleżeńską można przeprowadzić pod warunkiem, że zgodzą się na nią wszyscy uczestnicy, gdyż niektóre osoby mogą obawiać się krytyki, której skutkiem może być demotywacja uczącego się do zajęć językowych. Ocena koleżeńska powinna mieć charakter kontrolny, a nie być źródłem stresu i krytyki uczących się. W pracy z osobami 55+niezbędne jest stworzenie przyjaznej partnerskiej atmosfery, w której nie ma elementów rywalizacji (Berndt, 2000: 10-11).

Dziennik uczenia się pozwala na obserwowanie własnego procesu uczenia się i refleksję nad nim. Technika ta umożliwia notowanie nie tylko swoich indywidualnych celów krótko- bądź długoterminowych, planów, pozwala również na zapisanie spraw dzonych strategii i technik uczenia się języków obcych, swoich potrzeb, refleksji, pomysłów czy osiągnięć, co czyni dziennik dokumentem spersonalizowanym. Technika ta, jak pokazują badania, dobrze sprawdza się w pracy z osobami 55+(zob. Berndt, 2000: 8).

Konsultacje lub coaching językowy obejmują rozmowy uczącego się z nauczycielem, który pomaga mu w określeniu motywów, poznaniu stylu uczenia się, określeniu celów uczenia się, wskazuje też sposoby weryfikowania poczynionych postępów.

Listy umiejętności (tzw. checklist) umożliwiają poznanie, co uczący się potrafi, a nad czym musi jeszcze popracować. Zawierają one skale i kryteria oceny oraz przykłady, jak dokonać samooceny.

Arkusz obserwacyjny służy do monitorowania poczynionych postępów w pracy w określonym czasie, np. w ciągu tygodnia. Narzędzie to obejmuje informacje o poświęconym czasie na naukę, rodzaju aktywności w nauce języka obcego itp.

Jedną z wielu technik jest także określanie celów na początku zajęć i krótkie podsumowanie na ich koniec. Uczący się mogą w ten sposób ustalić swoje indywidualne, a także grupowe cele, które na koniec zajęć będą weryfikowane. Podczas podsumowania zajęć mają zaś możliwość wskazania aspektów dla nich niezrozumiałych lub szczególnie dla nich interesujących. W pracy z osobami 55+ ważna będzie regularność i systematyczność stosowania tej techniki (Berndt, 2000: 10). 
Kształtowanie umiejętności autoewaluacji u uczących się języka obcego w wieku...

Ostatnim z zaproponowanych rozwiązań jest prowadzenie portfolio językowego, czyli teczki z wytworami pracy uczących się. Mogą to być różnego rodzaju materiały do lekcji, prace pisemne, listy, notatki, obrazki pomagające w zapamiętaniu słów itd. Ta technika gromadzenia materiałów daje możliwość porównania wyników pracy w określonym czasie. Jest również dowodem na zrealizowanie ustanowionych celów, co może pozytywnie wpływać na obraz własnej osoby. Jednym z instrumentów przygotowanych przez Radę Europy wspierających kształtowanie samooceny osób 55+ jest Europejskie portfolio językowe (EPJ) (Berndt, 2003: 225; Raasch, 2008; Jaroszewska, 2014; Edlinger: 2016). Jest to narzędzie, które pomaga uczącym się zrozumieć celow ość kształcenia językowego, zmniejsza poziom lęku, pomagając zauważyć postęp i sukces oraz wzmacniając tendencję do uczenia się metodą prób i poszukiwań oraz poprawiania własnych błędów (Pamuła-Behrens, 2013). Dostępne są wersje zarówno dla edukacji wczesnoszkolnej, dla uczniów szkoły podstawowej, ponadpodstawowej i studentów (w tym dla przyszłych nauczycieli języków obcych oraz dla osób z dysfunkcjami narządu wzroku oraz niewidomych), a także dla dorosłych. Europejskie portfolio językowe dla dorosłych składa się, tak jak i pozostałe jego części, z trzech ściśle powiązanych ze sobą części: paszportu językowego, biografii językowej i dossier. Paszport językowy określa profil językowy oraz bilans doświadczeń interkulturowych uczącego się. Dokument ten zawiera dane właściciela, jego portret językowy, na który składają się samoocena, tabela samooceny, informacje od kiedy uczy się języków i jak ta nauka przebiega. Biografia językowa to indywidualny dokument zawierający wydarzenia związane z nauką języków oraz osobista refleksja uczącego się na temat własnych strategii uczenia się, potrzeb i celów uczenia się. Trzecia część dokumentu to dossier, czyli teczka zawierająca wybór prac i dokumentów uczącego się (dyplomy, zaświadczenia o udziale w kursach językowych, podróżach, pracy zarobkowej za granicą itd.).

Wprowadzając do nauki języka obcego EPJ, należy zdaniem niemieckiej badaczki Annette Berndt (2003) zachęcić osoby 55+do wyznaczania sobie na początku celów krótkoterminowych. Podobnego zdania jest również Mary Cay Ricci (2013), która uważa, że kształtowanie umiejętności autoewaluacyjnych powinno odbywać się w formie systematycznych treningów autoewaluacji. Do tego celu można wykorzystać pytania stawiane na zajęciach językowych, np.:

Jakie sq moje cele? Jakie mam zadanie do wykonania? Jak to zadanie wykonać? Czy potrzebuję pomocy? W jaki sposób wykonałam/wykonałem to zadanie? Czego się nauczyłam/nauczyłem? Czy wybrany przeze mnie sposób był najskuteczniejszy? Co móghbym zmienić, aby osiqgnqác jeszcze lepszy efekt? Co się działo podczas wykonywania zadania (cele, motywacja)? Czy jestem zadowoIona/zadowolony z rezultatu? Jeśli nie, to co mogę zmienić? 
Dodatkowo na zajęciach języków obcych samoocena może być kształtowana poprzez np. zachęcanie uczących się do planowania procesu uczenia się (np. dyskusję na temat tego, jak przygotować się do danego zadania), tworzenie krótkich podsumowań lekcji, samoocenę zadań domowych.

W pracy z osobami 55tna zajęciach języków obcych nie powinno zabraknąć wymiany doświadczeń na temat strategii uczenia się języków obcych oraz ich stylów uczenia się. Cenne pod tym względem jest nawiązywanie do wiedzy, umiejętności i technik uczenia się zdobytych i wykorzystywanych przez nich w nauce innych języków obcych (Jaroszewska, 2014: 208). Dobierając zakresy tematyczne, warto uwzględniać zainteresowania uczących się, ich doświadczenia, a także angażować ich do opracowywania tych zagadnień, z którymi są obeznani i które w ich przekonaniu stanowią ich mocną stronę.

\section{Podsumowanie}

Edukacja ustawiczna obejmuje proces uczenia się przez całe życie, w tym uczenia się języków obcych, a konieczność diagnozowania osiągnięć/postępów uczącego się jest jej nieodłącznym atrybutem. Ważną formą diagnozy jest autoewaluacja, która pozwala mu samodzielnie poznawać jego mocne i słabe strony i z czasem stawać się coraz bardziej świadomym, refleksyjnym odkrywcą języka obcego.

Osoby $55+$ stanowią bardzo złożoną i wymagającą grupę uczących się języka obcego, która potrzebuje specjalnego traktowania. Procesy regresywne w wieku 55+postępują szybko i są na tyle silne, że wyniki ewaluacji okresowej w ich przypadku bywają niekiedy niskie. Brak informacji na temat postępów czynionych przez uczących się może zaś oddziaływać negatywnie na ich motywację, gdyż jednym z powodów uczenia się języków obcych przez te osoby jest chęć sprawdzenia swoich możliwości. Samoocena w grupie 55+powinna więc przebiegać w pozytywnej atmosferze i skupiać się na mocnych stronach uczących się, tj. na ich nawet w niewielkim stopniu rosnących umiejętnościach, a nie na brakach. Osiągnięcia w nauce są dla nich ważne, gdyż pozwalają im zaspokajać potrzebę uznania, sukcesu (Jaroszewska, 2013). Są dla nich również widomym znakiem samorealizacji.

\section{BIBLIOGRAFIA}

Adamus M. (2004), Samoocena a zachowania społeczne. „Edukacja i Dialog”, nr 6, s. 64-67.

Baumann K. (2005), świadomość samego siebie. „Edukacja i Dialog”, nr 10, s. 27-31. Bandura A. (1997), Self-Efficacy: The Exercise of Control. New York: Freeman. 
Kształtowanie umiejętności autoewaluacji u uczących się języka obcego w wieku...

Berndt A. (2000), Senioren lernen Deutsch: 13 Grundgedanken. GFL - German as a foreign language. "German as a Foreign Language", nr 3, s. 1-14. Online: http:// www.gfl-journal.de/3-2000/berndt.pdf [DW 20.05.2019].

Berndt A. (2003), Sprachelernen im Alter. Eine empirische Studie zur Fremdsprachengeragogik. M ünchen: ludicium Verlag.

Biernat R. (2016), Troska o poczucie własnej wartości dzieci w rzeczywistości szkolnej - wymiar teoretyczny i praktyczne implikacje. „Społeczeństwo. Edukacja. Język", Państwowa Wyższa Szkoła Zawodowa w Płocku, s. 149-167.

Drwal R. Ł. (1995), Adaptacja kwestionariuszy osobowości. Wybrane zagadnienia i techniki. Warszawa: PWN.

Edlinger A. (2016), LanguAGEING: Fremdsprachen Lernen im Alter. Hamburg: disserta Verlag.

Flavell J. H. (1978), M etacognitive Development, (w:) Scandura, J. M ., Brainerd C. J. (red.), Structural/ Process Theories of Complex Human Behavior. Alphenaan den Rijn: Sijthoffand Noordhoff, s. 213-245.

Gage N. L., Berliner D.C. (1996), Pädagogische Psychologie. Weinheim: Beltz. Gardner D. (2000), Self-assessment for autonomous language learners. „Links \& Letters", nr 7, s. 49-60. Online: https://ddd.uab.cat/record/2281 [DW 20.05.2019].

Gindrich P. A. (2002), Funkcjonowanie psychospołeczne uczniów dyslektycznych. Lublin: Wydawnictwo Uniwersytetu Marii Curie- Skłodowskiej.

Grudziński A. (2012), Zasadnicze wymiary starzenia się i starości - biologiczny, psychiczny i społeczny, (w:) Zych A. A. (red.), Poznać, zrozumieć i zaakceptować starość. Łask: Spółka Over Group.

Jaroszewska A. (2011), Uczeń w wieku późnej dorosłości - próba charakterystyki w kontekście organizacji procesu nauczania języków obcych, (w:) Knieja J., Piotrowski S. (red.), Nauczanie języka obcego a specyficzne potrzeby uczących się. Lublin: Towarzystwo Naukowe KUL, s. 487-502. Jaroszewska A. (2013), Nauczanie języków obcych seniorów w Polsce. Analiza potrzeb i możliwości w aspekcie międzykulturowym. Kraków: Oficyna Wydawnicza "Impuls".

Jaroszewska A. (2014), 0 glottodydaktyce słowami glottodydaktyków. "Języki Obce w szkole", nr 4, s. 52-66. Online: http://jows.pl/sites/default/files/ jaroszewska_0.pdf [DW: 20.05.2019].

Jaworska M . (2008), Teoretyczne aspekty autoewaluacji w procesie uczenia się języków obcych. „Studia Germanica Gedanensia” nr 16, s. 119-131. Online: http://bazhum.muzhp.pl/media//files/Studia_Germanica_Ge danensia/Studia_Germanica_Gedanensia-r2008-t16/Studia_German ica_Gedanensia-ri2008-t16-s1119-131/Studia_Germanica_Gédanensi a-r2008-t16-s119-131.pdf [DW 20.05.2019]. 
Jaworska M . (2009), Autoewaluacja w procesie uczenia się i nauczania języków obcych. Zastosowanie „Europejskiego portfolia językowego” w kształceniu nauczycieli. Wrocław: Oficyna Wydawnicza ATUT.

Juczyński Z. (2000), Poczucie własnej skuteczności - teoria i pomiar. „Acta Universitatis Lodziensis. Folia Psychologica", nr 4, s. 11-23. Online: http:// bazhum.muzhp.pl/media//files/Acta_Universitatis_Lodziensis_Folia Psychologica/Acta_Universitatis_Lodżiensis_Folia_Psychologica-r200 0-t4/Acta_Universitatis_Lodziensis_Folia_Psychologica-r2000-t4-s11-23 /Acta_Universitatis_Lodziensis_Folia_Psychologica-r2000-t4-s11-23.pdf [DW 20.05.2019].

Kaczmarek A. (2002), Techniki wspomagania rozwoju autonomii, (w:) Wilczyńska W. (red.), Wokół autonomizacji w dydaktyce języków obcych: badania i refleksje. Poznań: Wydawnictwo UAM, s. 69-81.

Kic-Drgas J. (2013), Fremdsprachenlernen im Seniorenalter. Entwicklung und Evaluation von Lehr - und Lernmaterialien für Senioren. Wrocław Dresden: Neisse Verlag.

Kozielecki J. (1981), Psychologiczna teoria samowiedzy. Warszawa: PWN.

Kulas H. (1983), Mechanizm funkcjonowania samooceny. „Psychologia Wychowawcza", nr 4, s. 400-410.

Kulas H. (1986), Samoocena młodzieży. Warszawa: Wyższa Szkoła Pedagogiczna. Locke E.A., Latham G.P. (1990), A theory of goal setting and task performance. New York: Pearson College Div.

Niebrzydowski L. (1976), o poznawaniu i ocenie samego siebie. Warszawa: Nasza Księgarnia.

Niebrzydowski L (1989), Psychologia wychowawcza. Samoświadomość, aktywność, stosunki interpersonalne. Warszawa: Państwowe Wydawnictwo Naukowe.

Oxford R. L. (2017), Teaching and researching language learning strategies: Self-regulation in context. New York: Routledge.

Pamuła-Behrens M. (2013), „Europejskie portfolio językowe” krok po kroku. "Języki Obce w szkole", nr 3, s. 4-8. Online: http://jows.pl/sites/ default/ files/ pamula.pdf [DW: 20.05.2019].

Raasch, A. (2008), Ältere Menschen, das Sprachenlernen und Europa (w:) Schröder U. (red.), Blickpunkt Sprachen Entwicklungen, Projekte, Diskussionen. Impuls 33, Leonardo da Vinci. Bonn: Nationale Agentur Bildung für Europa beim Bundesinstitut für Berufsbildung, s. 118-128.

Ramírez-Gómez D. (2016), Language teaching and the older adult: The significance of experience. Bristol: Multilingual Matters.

Rampillon U., Zimmermann G. (1997), Strategien und Techniken beim Erwerb fremder Sprachen. München: Hueber. 
Ricci M .C. (2013), M indsets in the Classroom: Building a Culture of Success and Student Achievement in Schools. Waco, TX: Prufrock Press.

Rotter J. B. (1966), Generalized expectancies for internal versus external control of reinforcement. "Psychological M onographs", nr 80, s. 1-28.

Schunk D.H., Ertmer P.A. (1999), Self-regulatory processes during computer skill acquisition: Goal and self-evaluative influences. "Journal of Educational Psychology", nr 91, s. 251-260.

Steinbrich P. (2015), Samoocena w klasie językowej - donkiszoteria czy praca u podstaw? "J ezzyki Obce w Szkole" nr 3, s. 33-37. Online: http://jows. $\mathrm{pl}$ /sites/default/files/steinbrich.pdf [DW 20.05.2019].

Szatur-Jaworska B., Błędowski P., Dzięgielewska M . (2006), Podstawy gerontologii społecznej. Warszawa: Oficyna Wydawnicza Aspra-JR.

Szmagaj S. (2002), M iędzy „ja” realnym, a „ja” idealnym. „Edukacja i Dialog”, $\mathrm{nr}$ 6, s. 59-62.

Wenden A. L. (1991), Learner strategies for learner autonomy: Planning and implementing learner training for language learners. Hertfordshire: Prentice-Hall International.

Wilczyńska W. (1999), Uczyć się czy być nauczanym? O autonomii w przyswajaniu języka obcego. Warszawa-Poznań: Wydawnictwo Naukowe PWN.

Zimmerman B. J. (2002), Becoming a self-regulated learner: An overview. "Theory into Practice", nr 41(2), s. 64-70.

Zych A. A. (2007), Leksykon gerontologii. Kraków: Oficyna Wydawnicza „Impuls”.

Zych A.A., Kaleta-Witusiak M. (2010), Geragogika specjalna - moralnym obowiqzziem naszych czasów, (w:) Nowicka A. (red.), Wybrane problemy osób starszych. Kraków: Oficyna Wydawnicza „Impuls”, s. 27-41. 